\title{
Intravenous Fluid Use in an Indonesian Community Cohort 0-18 Months of Age
}

\section{Jarir At Thobari ( $\nabla$ j.atthobari@ugm.ac.id )}

Department of Pharmacology and Therapy, Faculty of Medicine, Public Health and Nursing, Universitas Gadjah Mada

Cahya Satria

Department of Child Health, Faculty of Medicine, Public Health and Nursing, Universitas Gadjah Mada

Kevin Johanes

Center for Child Health, Faculty of Medicine, Public Health and Nursing, Universitas Gadjah Mada

Jonathan Hasian Haposan

Center for Child Health, Faculty of Medicine, Public Health and Nursing, Universitas Gadjah Mada

\section{Emma Watts}

RV3 Rotavirus Vaccine Program, Murdoch Children's Research Institute, Parkville, Victoria

Jane Standish

RV3 Rotavirus Vaccine Program, Murdoch Children's Research Institute, Parkville, Victoria

\section{Amanda Handley}

Medicines Development for Global Health, Melbourne, Victoria

Novilia Bachtiar

PT Bio Farma

Julie Bines

Department of Gastroenterology and Clinical Nutrition, Royal Children's Hospital Melbourne, Parkville, Victoria

Yati Soenarto

Department of Child Health, Faculty of Medicine, Public Health and Nursing, Universitas Gadjah Mada

\section{Research Article}

Keywords: intravenous fluid administration, child cohort, Indonesia, intravenous fluid management

Posted Date: February 10th, 2021

DOI: https://doi.org/10.21203/rs.3.rs-140816/v1

License: (c) (7) This work is licensed under a Creative Commons Attribution 4.0 International License. Read Full License 


\section{Abstract \\ Background}

Intravenous fluid administration is one of the most common and important life-saving treatments in daily clinical settings, however it is not given as much attention as it should have. This study aims to evaluate the intravenous fluid's use pattern in infants from birth until 18 months of age in Indonesia.

\section{Methods}

A post-hoc analysis of RV3-BB Phase Ilb randomized, double-blinded, placebo-controlled trial was conducted in 1621 participants in Indonesia between January 2013 and July 2016. Any health events were documented in the trial as adverse events. Concomitant medication surveillance recorded all medications, including intravenous fluids (IVF) during the 18 months of follow-up. Information included intravenous fluid type, methods of administration, dosage, indication and duration.

\section{Results}

Of 1621 participants, 251 (15.48\%) participants received at least one intravenous fluid for treating 294 adverse events during their 18-month follow-up period. A total of 333 intravenous fluid consumptions were recorded, $20(6.0 \%)$ as fluid resuscitation, $273(81.98 \%)$ as fluid maintenance, 40 (12.01\%) as both maintenance and resuscitation. Isotonic fluids predominated resuscitation fluids (52 out of 60 [86.7\%]) and maintenance fluids (166 out of 313 [53.0\%]). Hyponatremia (1 case) was detected among those administered with hypotonic fluids (143 out 313 [45.7\%] IVFs) for maintenance fluid. The most common indication for intravenous fluid was gastroenteritis (31.6\%), with dehydration in most cases (65 [69.9\%]). Modified WHO's plan B diarrhea management was recorded in 22 [23.7\%] diarrhea cases.

\section{Conclusions}

This study provides the information of intravenous fluid use pattern in 0-18 months children cohort in Indonesia. Some intravenous fluids were found to be unnecessary and not optimal, exposing the patients to the avoidable risks. These data justify the further study to evaluate intravenous fluid use in children and the needs of continuing training on intravenous fluid management among healthcare providers.

\section{Trial registration:}

Trial registration: ACTRN12612001282875, Registered: 12/12/2012, https://www.anzctr.org.au/Trial/Registration/TrialReview.aspx? ACTRN=12612001282875

\section{Introduction}

Intravenous Fluids (IVF) are commonly indicated for acutely ill children who cannot receive sufficient fluid by enteral administration alone. This could be due to gastrointestinal disease, respiratory compromise, neurologic impairment, cardiac arrest, hypovolemic shock and other life-threatening conditions. (1-4) The main indications for IVF use include : (1) Cardio-vascular resuscitation, (2) Replacement of fluid and electrolyte deficits, and (3) to provide routine maintenance fluid and electrolyte requirements (5) with recently added consideration to (4) Redistribution of the fluid and (5) Reassessment of the IVF need during the therapy. (6) These ' 5 Rs' should always be considered before and during administration of IVF to patients. (6) Intravenous fluid should be administered adhering to the same rigorous standards as is required for drugs, and if there is no indication for IVF administration, then no IVF should be given. $(3,4)$ However, in clinical practice, these standards are all to commonly not be applied consistently, and IVF are sometimes administered despite not meeting an accepted indication, and not meeting recommendations for the dose and type of IVF for that clinical scenario. While IVF administration is a routine procedure in hospitals, research efforts allocated into this topic are still scarce. $(4,7,8)$

Complications resulting from inappropriate and incorrect IVF administration can be harmful. These range from local minor complications caused by incorrect intravenous cannulation (e.g. clotting, occlusion, leakage, infiltration, extravasation, phlebitis and infection) to systemic and lethal complications of incorrect intravenous fluid administration (e.g. hypo- or hypernatremia). $(3,4,9)$ Approximately 1 in 5 adult patients are reported to suffer harm from the complications of inappropriate IVF administration. (6) In order to tackle this issue we have to first understand the current practice of IVF administration in different settings.

In a WHO report published in 2011, an injection rate ranging from 0-7.8\% across 7 public facilities and 5 private facilities was reported in Indonesia, based on data provided from the Indonesian Ministry of Health. However, these data did not include injection and infusion use in any emergency department. There are no data specifically regarding the use of IVF across hospital inpatient and outpatient services in Indonesia. (10) To critically evaluate the use of IVF in Indonesia, including the appropriateness, safety and administration practices studies on are required. As part of a post-hoc analysis for RV3-BB vaccine trial population, along with the previous antimicrobial and non-antimicrobial studies, this study focused on IVF administration patterns in the trial participants. (11, 12) This study may help Indonesian and International authorities to assess and develop strategies in IVF administration policies.

\section{Methods}




\section{Study design}

The RV3-BB rotavirus vaccine phase Ilb randomized, double-blinded, placebo-controlled trial (Australian New Zealand Clinical Trials Registry number ACTRN12612001282875, registered date: 12/12/2012; the protocol is available at NEJM.org) was primarily done to assess the efficacy of the vaccine against severe rotavirus gastroenteritis on children up to 18 months old. Trial participants were divided into three randomised groups: neonatal-schedule and infantschedule vaccination, and placebo. Adverse events surveillance includes scheduled visit and weekly telephone calls by study personnel. The primary outcome from this study are episodes of severe rotavirus gastroenteritis from 2 weeks after 4 doses of investigational product. The secondary data obtained from this study are used to analyse the Intravenous Fluid use pattern on the participants during this study. The full design of this study will not be explained here as it has already been clarified in the main study. (13) This study aims to evaluate the intravenous fluid's use pattern in infants from birth until 18 months of age in Indonesia.

\section{Participants}

The main study, which was done in two districts of Yogyakarta and Central Java Province, Indonesia, from January 2013 to July 2016 , includes 1649 participants, of which 1621 participants' data are used in this study. There are 49 participants who were lost to follow up, however we still include their data in our study since some of them used at least one IVF and other medication. Figure 1 shows the pathway of how the participants were recruited. The data were obtained from 23 Primary Health Centres (PHCs) and 2 hospitals in the Sleman district (Yogyakarta Province) and the Klaten district (Central Java Province), representing the urban and rural area respectively. Healthy and full-term babies who weighed between 2500 and 4000 grams were included in this study, following written informed consent.

\section{Figure 1. Flow diagram of participants follow-up Intervention, randomisation and blinding}

The participants were divided into three groups: neonatal-schedule vaccine group, infant-schedule vaccine group, and placebo group. The participants received 4 doses, which consisted of 3 vaccine doses and 1 placebo dose, with exception for the placebo group who received 4 placebo doses. The schedule for the vaccinations was as follows: dose 1 at 0-5 days of age, dose 2 at 8-10 weeks of age, dose 3 at 14-16 weeks of age, and dose 4 at 18-20 weeks of age. The neonatal-schedule group received the placebo at the 4 th dose, while the infant-schedule group received the placebo at the 1 st dose.

The group intervention assignment was randomized with a computer code with a block size of 6 stratified by district. The trial assignment information was only available to the vaccine or placebo dispensing pharmacist at central pharmacy in each province, while both investigators and participants were blinded.

\section{Sample size}

To provide a power of $80 \%$, one-sided alpha of 0.1 and allow $10 \%$ dropout for the primary outcome of the assumed $3 \%$ severe gastroenteritis rotavirus, 549 participants per group were needed. In sub-study A, to compare the cumulative vaccine take, 94 participants per group were needed, meanwhile in sub-study B, to describe the proportion of infants with a positive seroprotective response against polio strains $1-3,111$ participants per group were needed. Since the sample size for the primary outcome is the largest, it is used as the study's sample size. The complete sample size calculation is described in the main study publication.(13)

\section{Intravenous Fluid}

All the participants who were included in this study were questioned weekly by phone call for any illness and medications (including intravenous fluid) that were administered to them during the 18-month period study. If they got sick, then attended the Primary health care clinic, or were hospitalized, then the data concerning intravenous fluids given to them are extracted from their medical records into electronic case report forms. In this study we did not give any treatment recommendation, including types of IVFs used and their indication. Treatment decisions were completely entrusted to the attending clinicians and routine local practices. Data obtained include intravenous fluid type, methods of administration, dosage, indication, start date and end date.

Based on WHO ATC codes (14) the IVFs are classified as (1) combinations of electrolytes, (2) combinations of electrolytes with carbohydrates, (3) carbohydrates, (4) electrolytes, (5) other blood products, and (6) blood substitutes and plasma protein fractions. All of these types of fluids, except for Other blood products and blood substitutes and plasma protein fractions, are what we call crystalloids. Other blood products and blood substitutes and plasma protein fractions can be regarded as colloids.

All illnesses or symptoms that occurred after the first dose of vaccine or placebo within the 18 months observation period were recorded as Adverse event (AE). AE were later classified with Medical Dictionary for Regulatory Activities (MedDRA) and subsequently narrowed down to 13 disease classes according to the affected organ systems. For diarrhea cases, dehydration level are based on WHO's Integrated Management of Childhood Illnesses (IMCI) guideline. (15)

\section{Ethical considerations}

This study was approved by Medical and Health Research Ethics Committee of Faculty of Medicine Universitas Gadjah Mada - Dr Sardjito General Hospital and the Royal Children's Hospital Melbourne Human research Ethics Committee. Written informed consents were obtained from the parents or guardians of every child during the RV3-BB phase Ilb trial. This post-hoc analysis only included those participants who gave consent for their data in the future studies.

\section{Statistical analysis}

Statistical calculations were performed by using SPSS version 25. For descriptive data, the results were presented as mean, median, frequency and percentages. Relationship between gender and vaccination groups with IV fluid use was assessed with Pearson chi-square. Relationships between the number 
of AEs and IVF Therapy use was assessed with independent samples t-test. Kolmogorov-Smirnoff test were used before hand to determine the normality for AEs for each participant.

\section{Results}

\section{Baseline characteristics}

Out of 1621 participants enrolled in this study, 251 participants (15.5\%) received Intravenous Fluid (IVF) at least once in the study period. Baseline characteristics of the participants are shown in Table 1 below. There are no significant differences in IVF use between gender groups and vaccination groups. Adverse events (AE) recorded per individual are significantly associated with IVF therapy $(p<0.05)$.

Table 1

Baseline characteristics of study participants

\begin{tabular}{|c|c|c|c|}
\hline Characteristics & $\begin{array}{l}\text { All } \\
(N=1621)\end{array}$ & $\begin{array}{l}\text { With IVF therapy } \\
(n=251)\end{array}$ & $\begin{array}{l}\text { Without IVF therapy } \\
(n=1370)\end{array}$ \\
\hline \multicolumn{4}{|l|}{ Sex, n (\%) } \\
\hline Male & $844(52.1)$ & $133(53)$ & $711(51.9)$ \\
\hline Female & $777(47.9)$ & $118(47)$ & $659(48.1)$ \\
\hline \multicolumn{4}{|l|}{ Vaccination group, $\mathrm{n}(\%)$} \\
\hline Neonatal schedule & $541(33.4)$ & $92(36.7)$ & $449(32.8)$ \\
\hline Infant schedule & $538(33.2)$ & $75(29.9)$ & $463(33.8)$ \\
\hline Placebo & $542(33.4)$ & $84(33.5)$ & $458(33.4)$ \\
\hline Participants suffering diarrhea event(s), n(\%) & $808(49.9)$ & $90(35.9)$ & $718(52.4)$ \\
\hline \multicolumn{4}{|l|}{ Sex, n (\%) } \\
\hline Male & $436(54)$ & $45(50)$ & $391(54.5)$ \\
\hline Female & $372(46)$ & $45(50)$ & $327(45.5)$ \\
\hline \multicolumn{4}{|l|}{ Vaccination Group, n (\%) } \\
\hline Neonatal & $266(32.9)$ & $31(34.4)$ & $235(32.7)$ \\
\hline Infants & $269(33.3)$ & $26(28.9)$ & $243(33.8)$ \\
\hline Placebo & 273(33.8) & $33(36.7)$ & $240(33.4)$ \\
\hline \multicolumn{4}{|l|}{ AEs recorded in all (1621) participants } \\
\hline Total AE, n (\%) & $9727(100)$ & $2069(21.2)$ & $7658(78.8)$ \\
\hline AE per participant, mean (SD) & $6.0 \pm 4.6$ & $8.2 \pm 4.9$ & $5.6 \pm 4.4$ \\
\hline
\end{tabular}

\section{Intravenous Fluid administration pattern}

The histogram in Fig. 2 depicts the age of participants at the start of intravenous fluid therapy. Notice that the IVF frequency decreases during the first 3 months of life, then peaks at the 9th month of life.

As seen in Table 2, there were 333 IVFs used for 294 AEs in 251 participants during the 18-month surveillance period of the study. Out of 9727 adverse effects, 121 AEs involved hospitalization, 14 AEs require IVFs and 280 involved both. The most common indication for IVF was for fluid maintenance (95.1\%). Among the IVFs intended for resuscitation (17.7\%), there was only one (0.3\%) intraosseous administration. The IVF fluids are commonly used singularly (76.1\% IVFs in $89.1 \%$ AEs), with only a few IVFs administered simultaneously or sequentially (21.3\%) for an adverse event (10.9\%). The most common IV drug classes that were given together with the IVFs are antibiotics in 113/294 (38.4\%) AEs and symptomatic medications (Non-Steroidal Anti-Inflammatory Drugs/NSAIDs, corticosteroids, antiemetics and proton pump inhibitors/PPIs) in 89/294 (30.3\%) AEs. There were 128/294 (43.5\%) AEs which require IV fluids without other concomitant IV drugs. 
The pattern of intravenous fluid use in children.

\begin{tabular}{|c|c|c|}
\hline Description & $\begin{array}{l}\text { Participants, } \\
\text { n (\%) } \\
n=251\end{array}$ & $\begin{array}{l}\text { AE Indication, } \\
n(\%) \\
n=294\end{array}$ \\
\hline \multicolumn{3}{|l|}{ Number of types of IVF } \\
\hline - One type of IVF & $191(76.1)$ & $262(89.1)$ \\
\hline - Two types of IVF* & $46(18.3)$ & $25(8.5)$ \\
\hline - Three types of IVF* & $9(3.6)$ & $7(2.4)$ \\
\hline$\cdot>3$ types of IVF* & $5(2.0)$ & $0(0)$ \\
\hline \multicolumn{3}{|l|}{ Route of administration } \\
\hline - Peripheral intravenous catheterization & $250(99.6)$ & $293(99.7)$ \\
\hline - Peripheral intravenous and Intraosseous catheterization & $1(0.4)$ & $1(0.3)$ \\
\hline IVF use without other concomitant IV drugs & $124(49.4)$ & $128(43.5)$ \\
\hline \multicolumn{3}{|l|}{ IVF use with concomitant IV drugs † } \\
\hline - Antibiotics ${ }^{\star \star}$ & $103(46.0)$ & $113(46.1)$ \\
\hline · Symptomatic medications ${ }^{\star \star}$ & $80(35.7)$ & $89(36.3)$ \\
\hline - Sedative hypnotics** & $22(9.8)$ & $24(9.8)$ \\
\hline - Other emergency drugs ${ }^{\star \star}$ & $13(5.8)$ & $13(5.3)$ \\
\hline • Supplements** & $6(2.7)$ & $6(2.4)$ \\
\hline - Total Concomitant IV drugs & $224(100)$ & $245(100)$ \\
\hline
\end{tabular}

\section{Types and indications of IVF use}

The types of IVF used in participants in this study are presented in Table 3. The characteristics and composition of the IVFs administered are presented in Table 4. The majority of the IVF administered in this study were crystalloid solutions with isotonic solutions being the mostly used (54.1\%) (Table 5). The IVF administration duration, as shown in Table 5, was not significantly different between the group that received isotonic IVF solution when compared to the group that received a hypotonic IVF solution ( $p>0.05$ ), but participants who receive hypotonic fluids are younger than those who receive isotonic fluids $(p<0.001)$. Intravenous Fluids which were used for AEs requiring resuscitation $(n=60)$ consist of $52(86.7 \%)$ isotonic fluids, $4(6.7 \%)$ blood products, $2(3.3 \%)$ colloids and $1(1.7 \%)$ hypotonic fluid (1 [1.7\%] missing fluid data), whereas IVFs $(n=313)$ which were used for maintenance in 287 AEs consists of $166(53.0 \%)$ isotonic fluids (in 165 [52.7\%] AEs which receive maintenance), 143 (46.1\%) hypotonic fluids (in 128 [44.6\%] AEs), 1 (0.3\%) hypertonic fluid and 1 (0.3\%) colloid (2 [0.6\%] missing data). We recorded 40 IVFs used for both resuscitation and maintenance fluids in 39 AEs. Mild asymptomatic hyponatremia was detected after administration of hypotonic IVF in $1 / 143(0.7 \%)$ hypotonic IVFs treatment for pneumonia. 
Table 3

Indication, duration, \& type of intravenous fluid used to the participants

\begin{tabular}{|c|c|}
\hline \multirow[t]{2}{*}{ Description } & Use of IVF \\
\hline & $N=333$ \\
\hline \multicolumn{2}{|l|}{ Fluid therapy indication, $n(\%)$} \\
\hline - Resuscitation & $20(6.3)$ \\
\hline - Maintenance & $273(82.3)$ \\
\hline - Resuscitation then maintenance & $40(11.4)$ \\
\hline Duration of each IVF treatment (days), median (range) & $4(1-13)$ \\
\hline \multicolumn{2}{|l|}{ Class and type of IVF, $n(\%)$} \\
\hline Combination of electrolytes & $195(58.6)$ \\
\hline - Ringer's Lactate & $164(49.25)$ \\
\hline - Tridex $27 A \AA$ & $19(5.7)$ \\
\hline - Ringer's Acetate & $11(3.3)$ \\
\hline - Half Ringer's Lactate with Dextrose $2.5 \%$ & $1(0.3)$ \\
\hline Combination of electrolytes with carbohydrates & $116(34.8)$ \\
\hline - Dextrose $5 \%$ in $0.45 \% \mathrm{NaCl}$ & $34(10.2)$ \\
\hline - Dextrose $5 \%$ in $0.225 \% \mathrm{NaCl}$ & $29(8.7)$ \\
\hline • KAEN 3A® & $27(8.1)$ \\
\hline - KAEN 3B® & $10(3.0)$ \\
\hline - KAEN 1B® & $7(2.1)$ \\
\hline - KAEN 4B® & $6(1.8)$ \\
\hline - Dextrose $10 \%$ in $0.225 \% \mathrm{NaCl}$ & $1(0.3)$ \\
\hline - Dextrose $5 \%$ in KAEN 1B & $1(0.3)$ \\
\hline - Dextrose $5 \%$ in $0.1 \% \mathrm{NaCl}$ & $1(0.3)$ \\
\hline \multicolumn{2}{|l|}{ Carbohydrates } \\
\hline - Dextrose $5 \%$ & $7(2.1)$ \\
\hline Electrolytes & $6(1.8)$ \\
\hline • $\mathrm{NaCl} 0.9$ & $5(1.5)$ \\
\hline - $\mathrm{NaCl} 3$ & $1(0.3)$ \\
\hline Other blood products & $4(1.2)$ \\
\hline - Packed Red Cell transfusion & $3(0.9)$ \\
\hline - Blood transfusion & $1(0.3)$ \\
\hline Blood substitutes and plasma protein fractions & $2(0.6)$ \\
\hline - Plasbumin $25 \AA$ & $1(0.3)$ \\
\hline - Hydroxyethyl Starch & $1(0.3)$ \\
\hline Missing data of IVF & $3(0.9)$ \\
\hline
\end{tabular}


Table 4

Intravenous fluids composition and characteristic

\begin{tabular}{|c|c|c|c|c|c|c|c|c|c|c|c|}
\hline $\begin{array}{l}\text { Intravenous } \\
\text { fluid }\end{array}$ & $\begin{array}{l}\mathrm{Na}+ \\
(\mathrm{mmol} / \mathrm{L})\end{array}$ & $\begin{array}{l}\mathrm{Cl}- \\
(\mathrm{mmol} / \mathrm{L})\end{array}$ & $\begin{array}{l}{[\mathrm{Na}+]:} \\
\text { Cl-] } \\
\text { ratio }\end{array}$ & $\begin{array}{l}\mathrm{K}+ \\
(\mathrm{mmol} / \mathrm{L})\end{array}$ & $\begin{array}{l}\text { Buffer } \\
\text { (mmol/L) }\end{array}$ & $\begin{array}{l}\mathrm{Ca} 2+ \\
\text { (mmol/L) }\end{array}$ & $\begin{array}{l}\mathrm{Mg} 2+ \\
(\mathrm{mmol} / \mathrm{L})\end{array}$ & $\begin{array}{l}\text { Glucose } \\
\text { (mmol/L) }\end{array}$ & $\begin{array}{l}\text { Osmolarity } \\
\text { (mOsm/L) }\end{array}$ & $\begin{array}{l}\text { Osmolarity } \\
\text { (compared to } \\
\text { plasma) }\end{array}$ & $\begin{array}{l}\text { Effective } \\
\text { Osmolai }\end{array}$ \\
\hline $\begin{array}{l}\text { Ringer's } \\
\text { Lactate }\end{array}$ & 130 & 109 & $1.19: 1$ & 4 & $\begin{array}{l}28 \\
\text { (lactate) }\end{array}$ & 2.7 & 0 & 0 & 273 & isosmolar & 273 \\
\hline $\begin{array}{l}\text { Half } \\
\text { Ringer's } \\
\text { Lactate in } \\
\text { Dextrose } \\
2.5 \% *\end{array}$ & 65 & 55 & $1.19: 1$ & 2 & 14 & 1.4 & 0 & 139 & 276 & Isosmolar & 136 \\
\hline $\begin{array}{l}\text { Asering® } \\
\text { (Ringer's } \\
\text { Acetate) }\end{array}$ & 130 & 112 & $1.16: 1$ & 5 & $\begin{array}{l}28 \\
\text { (acetate) }\end{array}$ & 1 & 1 & 0 & 276 & isosmolar & 276 \\
\hline $\begin{array}{l}\text { Tridex } \\
\text { 27A® }\end{array}$ & 60 & 50 & $1.2: 1$ & 10 & $\begin{array}{l}20 \\
\text { (lactate) }\end{array}$ & 0 & 0 & $\begin{array}{l}150(27 \\
\text { g) }\end{array}$ & 290 & isosmolar & 140 \\
\hline KA-EN 3A® & 60 & 50 & $1.2: 1$ & 10 & $\begin{array}{l}20 \\
\text { (lactate) }\end{array}$ & 0 & 0 & $\begin{array}{l}150(27 \\
\text { g) }\end{array}$ & 290 & isosmolar & 140 \\
\hline $\begin{array}{l}\text { Dextrose } \\
5 \% \text { in } \mathrm{NaCl} \\
0.1 \% *\end{array}$ & 17 & 17 & $1: 1$ & 0 & 0 & 0 & 0 & 278 & 312 & Isosmolar & 34 \\
\hline $\begin{array}{l}\text { Dextrose } \\
5 \% \text { in } \\
\mathrm{NaCl} \\
0.225 \% *+\end{array}$ & 38 & 38 & $1: 1$ & 0 & 0 & 0 & 0 & 278 & 354 & hyperosmolar & 77 \\
\hline $\begin{array}{l}\text { Dextrose } \\
5 \% \text { in } \\
\\
\mathrm{NaCl} \\
0.45 \% \dagger\end{array}$ & 77 & 77 & $1: 1$ & 0 & 0 & 0 & 0 & $\begin{array}{l}278(50 \\
\text { g) }\end{array}$ & 432 & hyperosmolar & 154 \\
\hline KA-EN 3B® & 50 & 50 & $1: 1$ & 20 & $\begin{array}{l}20 \\
\text { (lactate) }\end{array}$ & 0 & 0 & $\begin{array}{l}150(27 \\
\mathrm{g})\end{array}$ & 290 & isosmolar & 140 \\
\hline KA-EN 4B® & 30 & 28 & $1.07: 1$ & 8 & $\begin{array}{l}10 \\
\text { (lactate) }\end{array}$ & 0 & 0 & $\begin{array}{l}208 \\
(37.5)\end{array}$ & 284 & isosmolar & 76 \\
\hline KA-EN 1B® & 38.5 & 38.5 & $1: 1$ & 0 & 0 & 0 & 0 & $\begin{array}{l}208 \\
(37.5)\end{array}$ & 285 & isosmolar & 77 \\
\hline $\begin{array}{l}\text { Dextrose } \\
10 \% \text { in } \\
\mathrm{NaCl} \\
0.225 \% *\end{array}$ & 38 & 38 & $1: 1$ & 0 & 0 & 0 & 0 & 556 & 632 & hyperosmolar & 76 \\
\hline $\begin{array}{l}\text { KA-EN 1B® } \\
\text { in Dextrose } \\
5 \% *\end{array}$ & 38.5 & 38.5 & $1: 1$ & 0 & 0 & 0 & 0 & $\begin{array}{l}486 \\
(87.5)\end{array}$ & 563 & hyperosmolar & 77 \\
\hline $\mathrm{NaCl} 0.9 \%$ & 154 & 154 & $1: 1$ & 0 & 0 & 0 & 0 & 0 & 308 & isosmolar & 308 \\
\hline $\mathrm{NaCl} 3 \%$ & 513 & 513 & $1: 1$ & 0 & 0 & 0 & 0 & 0 & 1027 & hyperosmolar & 1027 \\
\hline $\begin{array}{l}\text { Dextrose } \\
5 \%\end{array}$ & 0 & 0 & - & 0 & 0 & 0 & 0 & $\begin{array}{l}278(50 \\
\mathrm{g})\end{array}$ & 278 & isosmolar & 0 \\
\hline
\end{tabular}

®Branded IVF, exact compositions are retrieved from the Indonesian National Agency of Drug and Food Control of Republic of Indonesia.

tWe recorded additions of potassium chloride solution into 1 of each of these fluids, thus the exact composition may vary slightly. 
Table 5

Fluid type and osmolarity category

\begin{tabular}{|c|c|c|c|c|c|}
\hline \multicolumn{2}{|c|}{ Fluid type and physiological osmolarity category } & Use of IVF, $n(\%)$ & Mean duration $\pm S D$ in day(s) & $\begin{array}{l}\text { Mean age } \pm S D \\
\text { in month(s) }\end{array}$ & $\begin{array}{l}\text { Hyponatremia } \\
\text { n (\%) }\end{array}$ \\
\hline \multirow[t]{3}{*}{ Crystalloids } & Isotonic & $180(54.1)$ & $3.67 \pm 1.9$ & $9.97 \pm 4.1$ & 0 \\
\hline & Hypotonic & $143(42.9)$ & $3.92 \pm 2.2$ & $7.78 \pm 4.9$ & $1(0.3)$ \\
\hline & Hypertonic & $1(0.3)$ & 2 & 8 & 0 \\
\hline \multirow[t]{3}{*}{ Colloid } & Blood Products & $4(1.2)$ & $1.5 \pm 1$ & $3.25 \pm 3.6$ & 0 \\
\hline & Albumin & $1(0.3)$ & 3 & 0 & 0 \\
\hline & Hydroxyethyl starch & $1(0.3)$ & 1 & 9 & 0 \\
\hline \multicolumn{2}{|c|}{ Missing data of IVF } & $3(0.9)$ & $2.0 \pm 1.7$ & $8.67 \pm 8.1$ & 0 \\
\hline \multicolumn{2}{|l|}{ Overall } & $333(100)$ & $3.72 \pm 2.1 \dagger$ & $8.90 \pm 4.7$ & $1(0.3)$ \\
\hline
\end{tabular}

\section{Adverse event indication for IVF use}

Adverse event (AE) in the Table 6 are the primary diagnose for each AE given IVFs. The most common indications for IVFs were gastroenteritis (93/294 [31.6\%]), lower respiratory tract infections (58/294 [19.7\%]), and febrile convulsions (33/294 [11.2\%]). Among IVF-treated AEs with gastroenteritis, we recorded $65 / 93$ (69.9\%) with some and severe dehydration as shown in Table 7. IVF treatment regimen for the diarrhea cases consists of $23 / 93$ (24.7\%) treated with modified plan B rehydration, $1 / 93$ (1.1\%) treated with plan C rehydration, 59/93 (63.4\%) treated with custom regimen and 10/93 (10.8\%) treated with unknown regimen. IVF was administered in 3/93 (3.2\%) diarrhea episodes with no assessment of dehydration, 25/879 (2.8\%) with no dehydration, 61/148 (41.2\%) with some dehydration, and $4 / 7(57.1 \%)$ with severe dehydration. 


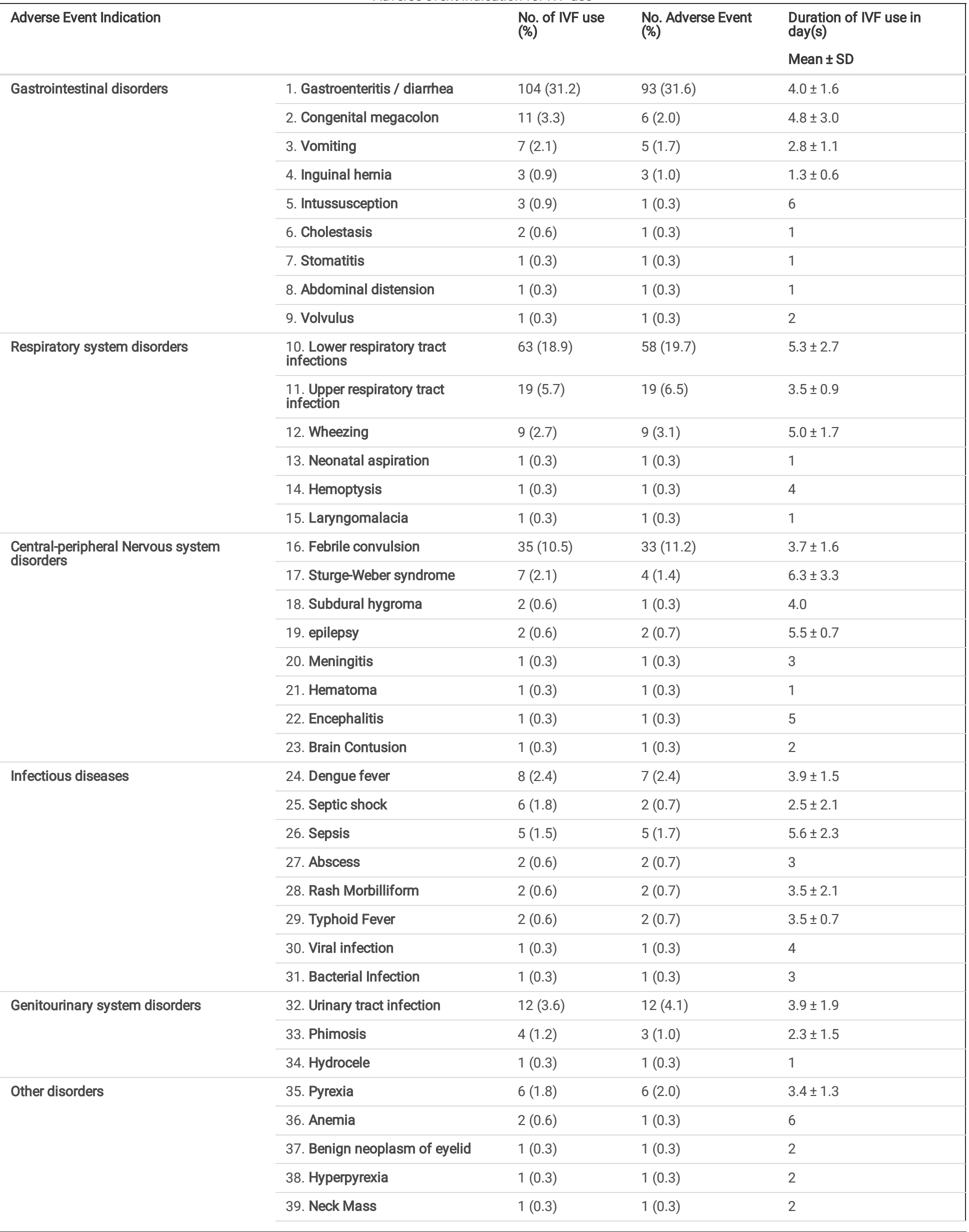




\begin{tabular}{|lllll|}
\hline Adverse Event Indication & $\begin{array}{l}\text { No. of IVF use } \\
(\%)\end{array}$ & $\begin{array}{l}\text { No. Adverse Event } \\
(\%)\end{array}$ & $\begin{array}{l}\text { Duration of IVF use in } \\
\text { day(s) } \\
\text { Mean } \pm \text { SD }\end{array}$ \\
\hline Total AE indications & 40. Cyst & $1(0.3)$ & $1(0.3)$ & 3 \\
\hline
\end{tabular}

Table 7

IVF management by dehydration's classification

\begin{tabular}{|c|c|c|c|c|}
\hline \multirow[t]{2}{*}{ Treatment plan } & \multicolumn{4}{|c|}{ Dehydration's Classification } \\
\hline & No assessment & No dehydration & Some dehydration & Severe dehydration \\
\hline No. of IVFs (\%) & $3(4.7)$ & $27(25.5)$ & $68(64.2)$ & $6(5.7)$ \\
\hline \multicolumn{5}{|l|}{$($ total $=104)$} \\
\hline No. of diarrhea event (\%) & $3(3.2)$ & $25(26.9)$ & $61(65.6)$ & $4(4.3)$ \\
\hline \multicolumn{5}{|l|}{ (total = 93) } \\
\hline \multicolumn{5}{|l|}{ Therapy and management* } \\
\hline • Plan B with IVF & $1(1.1)$ & $0(0)$ & $22(23.7)$ & $0(0)$ \\
\hline - Plan C & $0(0)$ & $0(0)$ & $0(0)$ & $1(1.1)$ \\
\hline - Custom † & $2(2.2)$ & $21(22.6)$ & $34(36.6)$ & $2(2.2)$ \\
\hline - Unknown $\ddagger$ & $0(0)$ & $4(4.3)$ & $5(5.4)$ & $1(1.1)$ \\
\hline \multicolumn{5}{|c|}{ * Data are shown as no. of diarrhea event (\% of total) } \\
\hline \multicolumn{5}{|c|}{ tCustom regimen is described as a customized fluid management but cannot be categorized into any plan based on IMCl guideli } \\
\hline \multicolumn{5}{|c|}{ ¥ Unknown regimen is described as unavailable data on specified fluid management from the case report form. } \\
\hline
\end{tabular}

Dehydration is recorded in 66/93 (71.0\%) diarrhea events which were given IVFs, and only 4/93 (4.3\%) of those events were assessed as severe dehydration based on IMCl. (15) Ringer's lactate was the most prescribed IVF for diarrhea (83\%), lower respiratory tract infection (38\%), febrile convulsion (40\%), Upper respiratory tract infection (42\%) and urinary tract infection (58.3\%). Dextrose solutions were mainly used in combination with other solutions, except 7 cases in the study used dextrose $5 \%$ solution alone for benign neoplasm of the eyelid, bronchiolitis, pneumonia, rhinopharyngitis, Sturge-Weber syndrome and wheezing. Whole blood transfusion and albumin were used together to treat cholestasis for 1 days. Hydroxyethyl starch was used to treat dengue shock syndrome. Packed Red Cells (PRC) were used together with either sodium chloride $0.9 \%$ to treat anemia, dextrose $5 \%$ in $0.225 \%$ sodium chloride for septic shock or $\mathrm{KA}-\mathrm{EN} 4 \mathrm{~B} \circledast$ to treat subdural hygroma. Hypertonic sodium chloride solution (3\%) was given as a combination with Ringer's lactate solution and with a rate of $1.5 \mathrm{ml}$ per hour, intended to correct the serum sodium concentration in a hyponatremic diarrhea case.

Among AEs which neither receive IV drugs, surgery, nor diarrhea event with dehydration (79 [26.9\%] events), we found 5/79 (6.3\%) dengue fever events requiring IVF as its main therapy; $10 / 79$ (12.7\%) events of febrile seizure, $1 / 79(1.3 \%)$ event of brain contusion and 1/79 (1.3\%) case of megacolon disease which might require emergency IV drugs or surgery. The rest of the AEs include 21/79 (26.6\%) diarrhea with no dehydration, 15/79 (19.0\%) LRTI, 10/79 (12.7\%) URTI, 8/79 (10.1\%) pyrexia, 4/79 (5.1\%) vomiting and 4/79 (5.1\%) others (hemoptysis, morbilliform rash, typhoid fever and viral infection); a total of $62(78.5 \%)$ of 79 events were given IVF with unknown assessment of ability to intake fluid orally.

\section{Discussion}

There are no previous studies that report the rate of IVF treatment in Indonesian community. Studies of the use of IVF are still limited which urge the need of further studies of IVF use in children. The age of the event onset requiring IVFs (Fig. 2) suggested that intravenous fluid use was decreasing starting from 3 months old, before starting to to raise until the peak at 9 months old. In this study, participants who received IVF in the neonatal period were associated with gastrointestinal disorders and infectious diseases (predominantly neonatal sepsis). The major disease occurring at first 2 months of age was respiratory system disorders, while the older ages were predominantly gastrointestinal disorders and respiratory disorders.

IVFs in this study was almost exclusively administered by peripheral IV catheterization. About 55/294 (18.7\%) events with IV cathether in this study spent more than 5 days (but less than 15 days. The Michigan Appropriateness Guide for Intravenous Catheters (MAGIC) mentions 7 methods of IVF administration. The most common method, peripheral IV catheterization, is recommended for anticipated IV administration duration of less than 6 days. Beyond that period, other methods such as ultrasonography guided peripheral intravenous catheterization are preferred. (20) Estimating the duration of IV administration, however, is difficult. Ultrasound-guided IV cannulation is more commonly indicated for difficult IV access, such as in obese patients. (21) Absence of other IV catheterization technique (other than peripheral IV catheterization and IO catheterization) in the participants shows the need to explore this topic more, as it might help to improve IV practices in Indonesia. 
More than half of total AE indications, based on our study, were given IVF and other concomitant drugs. Peripheral intravenous catheterization is indicated for intravenous (IV) drug administration, IV hydration, transfusion, surgery, emergency care, and in other situations that requires direct IV access. (22) Indications of IV catheterization includes those of IVF, but not vice versa. An article about IV catheterization mention that only 50\% of Peripheral IV cannulation (PIVC) were used after installation in the emergency department, and the PIVCs used were intended for fluids only (18.9\%), drugs only (40.6\%) or both (40.6\%). (23) Their finding shows that sometimes PIVC can be used only for IV drugs, without IVFs as well. However, we could not find any article which can recommend whether IVFs should be used together with IV drugs or not, when only IV drugs are needed.

In this study, gastrointestinal disease was the most common indication for IVF administration. In treating diarrhea, intravenous fluid administration is usually indicated for treatment of dehydration $(2,19,24)$. Only $4(4.3 \%)$ diarrhea events actually needed IVF because of severe dehydration. However, the rest of $69.9 \%$ diarrhea events were not assessable because of unknown hydration status or unknown ability to intake fluid orally. Some diarrhea events recorded no dehydration (25.8\%) but were given IVFs, even though there was no identifiable indication for IVF at all. Based on this study, we can only conclude that only $4.3 \%$ IVF administration was justifiable in diarrhea events, with at least $25.8 \%$ IVF administrations errors.

Among 4 diarrhea events with severe dehydration,only 1 (25\%) participant received Plan C rehydration regimen. Among 62 diarrheas with some dehydration, 22 (35.5\%) diarrhea events were treated with modified plan B rehydration regimen. The plan B mentioned in this study is a modified WHO plan B rehydration with an addition of IVF infusion, which lacks evidence and has uncertain effectiveness. According to the Indonesian Pediatric Society handbook, IMCl and WHO pocket guide, treatment of diarrhea are categorized into plan A, intended for diarrhea with no dehydration, which require Oral Rehydration Solution (ORS) for ongoing body fluid loss; plan B, intended for some dehydration, which require ORS for fluid replacement and ongoing loss, except for participants with profuse vomiting, who can be treated with IVFs; and plan C, intended for severe dehydration, which require fluid replacement via intravenous or Nasogastric Tube and ORS to replace ongoing loss. $(2,15,25)$ This finding shows that only $1(1 \%)$ IVF was used for the right indication and with the right regimen in diarrhea events.

In this study, isotonic fluid was the most used fluid, but a high percentage of hypotonic fluid was still being used. Hypotonic fluids tend to be given to younger participants; this shows that some IVF practices were still based on old theory made by Holliday-Segar. (26) The most frequent IVFs used for maintenance is isotonic fluid, but a large proportion of hypotonic fluids are also used for maintenance fluid. The Indonesian Pediatrics Society's handbook mentioned how much fluid should be administered based on the patient's weight and they also mentioned to use Dextrose $5 \%$ in $0.45 \% \mathrm{NaCl}$ solution as the fluid of choice for maintenance of Diabetic Ketoacidosis case; however, there is no recommendation of IVF of choice in general. (25) Long standing WHO recommendations stated to use either isotonic or hypotonic IVFs for maintenance IVFs (2) but present studies recommends only isotonic fluids for maintenance (except for neonates) because it is less likely to cause adverse events in children. $(1,19,24)$ A study in England $(2015)$, showed that 118 (59\%), 63 (32\%) and 19 (10\%) pediatric patients receive hypotonic, isotonic and hypertonic maintenance respectively. (27) Compared to their finding, maintenance IVF practices in the study showed better adherence to isotonic fluids as maintenance fluid. Even then, we cannot disregard the fact that a large proportion of maintenance fluid in this study were hypotonic fluids.

In our study, 1 case of hyponatremia was detected after a hypotonic fluid administration indicated for pneumonia, on the contrary there is no hyponatremia detected in those who were treated with isotonic fluid. This shows that fluid administration practices can still be optimized to reduce the risk of complications by simply selecting the right choice of fluids.

The most used resuscitation fluid is isotonic fluids, with only a small fraction of hypotonic fluids being used. This finding shows that clinical practice of fluid resuscitation during the duration of the study is good and almost all of clinicians comply to Indonesian Pediatric Society handbook guideline to use isotonic fluid for resuscitation. (25) Recommendations for resuscitative fluids is adamant on using isotonic fluids $(1,2,19,24)$, except perhaps in case of malnutrition (2) Comparisons of different recommendations for maintenance and resuscitative fluids from different sources are described at Table 8. 
Table 8

Comparisons between recommendations of maintenance IVF regimens

\begin{tabular}{|c|c|c|c|c|}
\hline Reference & Age & IVF choice & Regimens & Notes \\
\hline \multirow[t]{6}{*}{ (2) } & \multirow{6}{*}{$\begin{array}{l}<5 \text { years } \\
\text { old }\end{array}$} & Neonates: & Neonates: & \multirow{4}{*}{$\begin{array}{l}\text {-Give more fluid if the neonate is under radiant } \\
\text { warmer (1.2-1.5 times).(2) } \\
\text {-Every } 1^{\circ} \mathrm{C} \text { increase of body temperature should } \\
\text { be accompanied by an increase of } \\
10 \% \text { maintenance fluid needs.(2) }\end{array}$} \\
\hline & & \multirow{3}{*}{$\begin{array}{l}\text { First } 2 \text { days give D10, afterwards } \\
\text { use } 1 / 2 \text { NS + D5 }\end{array}$} & \multirow{3}{*}{$\begin{array}{l}\text {-day-1: } 60 \mathrm{ml} / \mathrm{kg} / \text { day -day-3: } 120 \\
\mathrm{ml} / \mathrm{kg} / \mathrm{day} \\
\text {-day-2: } 90 \mathrm{ml} / \mathrm{kg} / \text { day -then } \\
\text { increase to } 150 \mathrm{ml} / \mathrm{kg} / \text { day }\end{array}$} & \\
\hline & & & & \\
\hline & & & & \\
\hline & & Children: & For children under 5 years old, a & -Limit: $2500 \mathrm{ml}$ for boys and $2000 \mathrm{ml}$ for girls.(19) \\
\hline & & $\begin{array}{l}\mathrm{RL}+\mathrm{D} 5, \mathrm{NS}+\mathrm{D} 5 \text { or } 1 / 2 \mathrm{NS}+ \\
\text { D5/D10 }\end{array}$ & $\begin{array}{l}100 \mathrm{ml} / \mathrm{kg} \text { for the } 1 \mathrm{st} 10 \mathrm{~kg}, 50 \\
\mathrm{ml} / \mathrm{kg} \text { for the } 2 \mathrm{nd} 10 \mathrm{~kg}, 25 \mathrm{ml} / \mathrm{kg} \\
\text { after } 20 \mathrm{~kg}\end{array}$ & $\begin{array}{l}\text {-For term neonates in critical postnatal adaptation } \\
\text { phase give minimal to no sodium until postnatal } \\
\text { diuresis with weight loss occurs.(19) }\end{array}$ \\
\hline \multirow[t]{3}{*}{ (1) } & \multirow[t]{3}{*}{$\begin{array}{l}28 \text { days - } \\
18 \text { years old }\end{array}$} & \multirow{3}{*}{$\begin{array}{l}\text {-For the specified age, use NS + } \\
\text { D5 with (if there are no } \\
\text { contraindications for potassium) } \\
20 \mathrm{mEq} / \mathrm{L} \mathrm{KCl}\end{array}$} & & \multirow{4}{*}{$\begin{array}{l}\text {-If there is a risk of ADH secretion: restrict fluid to } \\
50-80 \% \text { needs or estimate insensible loss of } \\
300-400 \mathrm{ml} / \mathrm{m} 2 \mathrm{BSA} / 24 \text { hours plus urine output. } \\
(19,24) \\
\text {-Regimen for preterm/low birth weight not shown }\end{array}$} \\
\hline & & & Hourly rate of $4 \mathrm{~mL} / \mathrm{kg}$ for the first & \\
\hline & & & $\begin{array}{l}10 \mathrm{~kg}, 2 \mathrm{~mL} / \mathrm{kg} \text { for the second } 10 \\
\mathrm{~kg} \text {, then } 1 \mathrm{~mL} / \mathrm{kg} \text { after } 20 \mathrm{~kg} \text {. }\end{array}$ & \\
\hline \multirow[t]{6}{*}{ (19) } & \multirow[t]{6}{*}{$\begin{array}{l}<16 \text { years } \\
\text { old }\end{array}$} & -Term neonates: & Neonates ( $\leq 28$ days old): & \\
\hline & & \multirow[t]{3}{*}{ isotonic fluid with D5/D10 } & $\begin{array}{l}\text { day- } 1: 50-60 \mathrm{ml} / \mathrm{kg} / \text { day day-4: } \\
100-120 \mathrm{ml} / \mathrm{kg} / \mathrm{day}\end{array}$ & \\
\hline & & & $\begin{array}{l}\text { day-2: } 70-80 \mathrm{ml} / \mathrm{kg} / \text { day day }-5 \text { till } \\
28: 120-150 \mathrm{ml} / \mathrm{kg} / \text { day }\end{array}$ & \\
\hline & & & day-3: $80-100 \mathrm{ml} / \mathrm{kg} /$ day & \\
\hline & & \multirow{2}{*}{$\begin{array}{l}\text {-Children: } \\
\text { isotonic crystalloid containing } \\
131-154 \mathrm{mmol} / \text { liter of sodium }\end{array}$} & $\begin{array}{l}\text { Children } \geq 29 \text { days until } 16 \text { years } \\
\text { old, with daily rate of: }\end{array}$ & \\
\hline & & & $\begin{array}{l}100 \mathrm{ml} / \mathrm{kg} \text { for the first } 10 \mathrm{~kg},+50 \\
\mathrm{ml} / \mathrm{kg} \text { for the second } 10 \mathrm{~kg},+20 \\
\mathrm{ml} / \mathrm{kg} \text { after that }\end{array}$ & \\
\hline \multicolumn{5}{|c|}{ Hypovolemic shock } \\
\hline \multirow[t]{4}{*}{ (2) } & $\begin{array}{l}<5 \text { years no } \\
\text { malnutrition }\end{array}$ & RL or NS & $\begin{array}{l}20 \mathrm{ml} / \mathrm{kg} \text { as rapid as possible up to } \\
3 \text { times, then consider epinephrine } \\
\text { or dopamine }\end{array}$ & $\begin{array}{l}\text {-If there is hypokalemia, then add } 40 \mathrm{mmol} / \mathrm{L} \text { of } \\
\text { Potassium until it reaches normal value, then } \\
\text { reduce to } 20 \mathrm{mmol} / \mathrm{L}(24)\end{array}$ \\
\hline & \multirow{3}{*}{$\begin{array}{l}<5 \text { years } \\
\text { old with } \\
\text { severe } \\
\text { malnutrition }\end{array}$} & $\mathrm{RL}+\mathrm{D} 5 /$ & $15 \mathrm{ml} / \mathrm{kg}$ in 1 hour up to 2 times & \\
\hline & & $\begin{array}{l}\text { half strength Darrow's solution + } \\
\text { D5/ }\end{array}$ & \multirow{2}{*}{$\begin{array}{l}\text { if there are improvements \& no } \\
\text { pulmonary edema switch to enteral } \\
\text { ReSoMal } \\
\text { if there are no improvement give } \\
\text { maintenance IVF, transfuse Whole } \\
\text { Blood (or PRC if child has cardiac } \\
\text { failure) }\end{array}$} & \\
\hline & & $1 / 2$ NS + D5 & & \\
\hline (19) & $\begin{array}{l}\text { under } 16 \\
\text { years old }\end{array}$ & $\begin{array}{l}\text { glucose free isotonic crystalloids } \\
\text { containing } 131-154 \mathrm{mmol} / \mathrm{liter} \\
\text { of sodium }\end{array}$ & $\begin{array}{l}\text { children: } 20 \mathrm{ml} / \mathrm{kg} \text { in less than } 10 \\
\text { minutes }\end{array}$ & \\
\hline & & & $\begin{array}{l}\text { term neonates: } 10-20 \mathrm{ml} / \mathrm{kg} \text { in } \\
\text { less than } 10 \text { minutes up to } 40-60 \\
\mathrm{ml} / \mathrm{kg} \text { then consult to a specialist }\end{array}$ & \\
\hline \multirow[t]{2}{*}{$(24)$} & \multirow[t]{2}{*}{-} & potassium free & \multirow{2}{*}{$\begin{array}{l}20 \mathrm{ml} / \mathrm{kg} \text { in less than } 10 \text { minutes, } \\
\text { up to } 3 \text { times, then consider } \\
\text { epinephrine or dopamine }\end{array}$} & \\
\hline & & $0.9 \% \mathrm{NS}+\mathrm{D} 5$ & & \\
\hline
\end{tabular}

Abbreviations: NS $=$ Normal Saline or $0.9 \%$ sodium chloride solution; $\mathrm{D} 5 / 10=5 \% / 10 \%$ Dextrose solution; $\mathrm{RL}=\mathrm{Ringer}$ 's $\mathrm{Lactate}$ solution; $\mathrm{KCl}=$ potassium chloride. 
Table 8

Comparisons between recommendations of maintenance IVF regiments

\begin{tabular}{|c|c|c|c|c|}
\hline Reference & Age & IVF choice & Regiment & Notes \\
\hline \multirow[t]{7}{*}{ (2) } & \multirow[t]{7}{*}{$\begin{array}{l}<5 \text { years } \\
\text { old }\end{array}$} & \multirow[t]{3}{*}{ Neonates: } & \multirow[t]{3}{*}{ Neonates: } & $\begin{array}{l}\text {-Give more fluid if the neonate is under radiant } \\
\text { warmer (1.2-1.5 times).(2) }\end{array}$ \\
\hline & & & & $\begin{array}{l}\text {-Every } 1^{\circ} \mathrm{C} \text { increase of body temperature should } \\
\text { be accompanied by an increase of }\end{array}$ \\
\hline & & & & $10 \%$ maintenance fluid needs.(2) \\
\hline & & \multirow[t]{2}{*}{$\begin{array}{l}\text { First } 2 \text { days give D10, afterwards } \\
\text { use } 1 / 2 \text { NS + D5 }\end{array}$} & $\begin{array}{l}\text {-day-1: } 60 \mathrm{ml} / \mathrm{kg} / \text { day -day-3: } 120 \\
\mathrm{ml} / \mathrm{kg} / \text { day }\end{array}$ & -Limit: $2500 \mathrm{ml}$ for boys and $2000 \mathrm{ml}$ for girls.(19) \\
\hline & & & $\begin{array}{l}\text {-day-2: } 90 \mathrm{ml} / \mathrm{kg} / \mathrm{day} \text {-then } \\
\text { increase to } 150 \mathrm{ml} / \mathrm{kg} / \mathrm{day}\end{array}$ & \multirow{3}{*}{$\begin{array}{l}\text {-For term neonates in critical postnatal adaptation } \\
\text { phase give minimal to no sodium until postnatal } \\
\text { diuresis with weight loss occurs.(19) } \\
\text {-If there is a risk of ADH secretion: restrict fluid to } \\
50-80 \% \text { needs or estimate insensible loss of } \\
300-400 \mathrm{ml} / \mathrm{m} 2 \mathrm{BSA} / 24 \text { hours plus urine output. } \\
(19,24) \\
\text {-Regiment for preterm/low birth weight not shown }\end{array}$} \\
\hline & & & $\begin{array}{l}\text { For children under } 5 \text { years old, a } \\
\text { daily rate of: }\end{array}$ & \\
\hline & & $\begin{array}{l}\mathrm{RL}+\mathrm{D} 5, \mathrm{NS}+\mathrm{D} 5 \text { or } 1 / 2 \mathrm{NS}+ \\
\mathrm{D} 5 / \mathrm{D} 10\end{array}$ & $\begin{array}{l}100 \mathrm{ml} / \mathrm{kg} \text { for the } 1 \mathrm{st} 10 \mathrm{~kg}, 50 \\
\mathrm{ml} / \mathrm{kg} \text { for the } 2 \mathrm{nd} 10 \mathrm{~kg}, 25 \mathrm{ml} / \mathrm{kg} \\
\text { after } 20 \mathrm{~kg}\end{array}$ & \\
\hline \multirow[t]{2}{*}{ (1) } & \multirow{2}{*}{$\begin{array}{l}28 \text { days - } \\
18 \text { years old }\end{array}$} & \multirow{2}{*}{$\begin{array}{l}\text {-For the specified age, use NS + } \\
\text { D5 with (if there are no } \\
\text { contraindications for potassium) } \\
20 \mathrm{mEq} / \mathrm{L} \mathrm{KCl}\end{array}$} & $1500 \mathrm{ml} / \mathrm{m}^{2} /$ day or & \\
\hline & & & $\begin{array}{l}\text { Hourly rate of } 4 \mathrm{~mL} / \mathrm{kg} \text { for the first } \\
10 \mathrm{~kg}, 2 \mathrm{~mL} / \mathrm{kg} \text { for the second } 10 \\
\mathrm{~kg} \text {, then } 1 \mathrm{~mL} / \mathrm{kg} \text { after } 20 \mathrm{~kg} .\end{array}$ & \\
\hline \multirow[t]{6}{*}{ (19) } & \multirow{6}{*}{$\begin{array}{l}<16 \text { years } \\
\text { old }\end{array}$} & \multirow{4}{*}{$\begin{array}{l}\text {-Term neonates: } \\
\text { isotonic fluid with D5/D10 }\end{array}$} & Neonates ( $\leq 28$ days old): & \\
\hline & & & $\begin{array}{l}\text { day- } 1: 50-60 \mathrm{ml} / \mathrm{kg} / \text { day day }-4: \\
100-120 \mathrm{ml} / \mathrm{kg} / \mathrm{day}\end{array}$ & \\
\hline & & & $\begin{array}{l}\text { day-2: } 70-80 \mathrm{ml} / \mathrm{kg} / \text { day day- } 5 \text { till } \\
28: 120-150 \mathrm{ml} / \mathrm{kg} / \text { day }\end{array}$ & \\
\hline & & & day-3: $80-100 \mathrm{ml} / \mathrm{kg} /$ day & \\
\hline & & \multirow{2}{*}{$\begin{array}{l}\text {-Children: } \\
\text { isotonic crystalloid containing } \\
131-154 \mathrm{mmol} / \text { liter of sodium }\end{array}$} & $\begin{array}{l}\text { Children } \geq 29 \text { days until } 16 \text { years } \\
\text { old, with daily rate of: }\end{array}$ & \\
\hline & & & $\begin{array}{l}100 \mathrm{ml} / \mathrm{kg} \text { for the first } 10 \mathrm{~kg},+50 \\
\mathrm{ml} / \mathrm{kg} \text { for the second } 10 \mathrm{~kg},+20 \\
\mathrm{ml} / \mathrm{kg} \text { after that }\end{array}$ & \\
\hline \multicolumn{5}{|c|}{ Hypovolemic shock } \\
\hline \multirow[t]{4}{*}{ (2) } & $\begin{array}{l}<5 \text { years no } \\
\text { malnutrition }\end{array}$ & RL or NS & $\begin{array}{l}20 \mathrm{ml} / \mathrm{kg} \text { as rapid as possible up to } \\
3 \text { times, then consider epinephrine } \\
\text { or dopamine }\end{array}$ & $\begin{array}{l}\text {-If there is hypokalemia, then add } 40 \mathrm{mmol} / \mathrm{L} \text { of } \\
\text { Potassium until it reaches normal value, then } \\
\text { reduce to } 20 \mathrm{mmol} / \mathrm{L}(24)\end{array}$ \\
\hline & \multirow{3}{*}{$\begin{array}{l}<5 \text { years } \\
\text { old with } \\
\text { severe } \\
\text { malnutrition }\end{array}$} & \multirow{3}{*}{$\begin{array}{l}\mathrm{RL}+\mathrm{D} 5 / \\
\text { half strength Darrow's solution + } \\
\text { D5/ } \\
1 / 2 \mathrm{NS}+\mathrm{D} 5\end{array}$} & \multirow{3}{*}{$\begin{array}{l}15 \mathrm{ml} / \mathrm{kg} \text { in } 1 \text { hour up to } 2 \text { times } \\
\text { if there are improvements \& no } \\
\text { pulmonary edema switch to enteral } \\
\text { ReSoMal } \\
\text { if there are no improvement give } \\
\text { maintenance IVF, transfuse Whole } \\
\text { Blood (or PRC if child has cardiac } \\
\text { failure) }\end{array}$} & \\
\hline & & & & \\
\hline & & & & \\
\hline \multirow[t]{2}{*}{ (19) } & \multirow[t]{2}{*}{$\begin{array}{l}\text { under } 16 \\
\text { years old }\end{array}$} & \multirow[t]{2}{*}{$\begin{array}{l}\text { glucose free isotonic crystalloids } \\
\text { containing } 131-154 \mathrm{mmol} / \mathrm{liter} \\
\text { of sodium }\end{array}$} & $\begin{array}{l}\text { children: } 20 \mathrm{ml} / \mathrm{kg} \text { in less than } 10 \\
\text { minutes }\end{array}$ & \\
\hline & & & $\begin{array}{l}\text { term neonates: } 10-20 \mathrm{ml} / \mathrm{kg} \text { in } \\
\text { less than } 10 \text { minutes up to } 40-60 \\
\mathrm{ml} / \mathrm{kg} \text { then consult to a specialist }\end{array}$ & \\
\hline \multirow[t]{2}{*}{$(24)$} & \multirow[t]{2}{*}{-} & potassium free & \multirow{2}{*}{$\begin{array}{l}20 \mathrm{ml} / \mathrm{kg} \text { in less than } 10 \text { minutes, } \\
\text { up to } 3 \text { times, then consider } \\
\text { epinephrine or dopamine }\end{array}$} & \\
\hline & & $0.9 \% \mathrm{NS}+\mathrm{D} 5$ & & \\
\hline
\end{tabular}

Isotonic fluids were the mostly used IVF to treat diarrheas, but hypotonic IVFs have been used occasionally for isonatremic diarrheas and might not be the optimal choice. Diarrhea influences body electrolytes and as such, different types of dehydrations might occur, which include hyponatremic, isonatremic and hypernatremic dehydration, which can all be treated with $5 \%$ dextrose in $0.9 \%$ normal saline. (24) In the only event of hyponatremic diarrhea (1[1.1\%] of all diarrhea events), hypertonic saline was administered with Ringer's Lactate to correct the serum sodium level. Hypertonic saline is recommended in case of symptomatic hyponatremic dehydration but as the participant was assessed with mild hyponatremia, normal saline might prove to be the better option. (24) 
Some intravenous fluid choice for children with diarrhea used hypotonic fluid as maintenance in this study, which is not optimal and shows that IVF practices have not been in compliance with the latest recommendation.

In this study, blood transfusion was performed in 2 participants with 9.3-9.6 $\mathrm{g} / \mathrm{dL}$ for pretransfusion hemoglobin (Hb) level and $13.3-14.1 \mathrm{~g} / \mathrm{dL}$ for posttransfusion $\mathrm{Hb}$ level. Latest recommendations state that the more restrictive $\mathrm{Hb}$ threshold $(7 \mathrm{~g} / \mathrm{dL})$ for transfusion reduces blood use and does not result in worse outcome in pediatric intensive care unit. (28) The target $\mathrm{Hb}$ concentration recommended is around 8.5-9.5 g/dL. (29) The higher threshold might be justifiable when indicated for the participant with intracranial hemorrhage, because the participant is hemodynamically unstable, but questionable for the participant with cholestasis. Implementation of more restrictive $\mathrm{Hb}$ threshold might give more benefit than harm.

Colloid use in this study was Hydroxyethyl starch (HES) and albumin indicated for dengue hemorrhagic fever and cholestasis, respectively. The participant treated with HES was suffering from a fatal dengue shock syndrome. After resuscitation with Ringer's Lactate, she was given HES, following WHO's treatment algorithm (30). Albumin is not only intended for volume expansion. In this study it was intended to correct hypoalbuminemia at a concentration of $2 \mathrm{~g} / \mathrm{dL}$ in a case of cholestasis. Although Indonesian guideline recommended to correct albumin in case of hypoalbuminemia in nephrotic syndrome, there is no recommendation in cholestasis. (25) furthermore, this effort to correct albumin without other primary indication such as hypovolemia or major surgery might be unnecessary. $(31,32)$

The study reflects the patterns of IVF administration use in infants and young children in Yogyakarta and Central Java province, and as far as we know, IVFs were administered improperly in the community, and some choice of intravenous fluid used for the participants in this study is not optimal. Practitioners' knowledge and skills towards intravenous fluid management in children plays a major role in determining the rationality of the treatment, and Mahapatra et al. found that practitioners who live in poor and resource-scarce area have a tendency to be less competent than those who lived in more developed area, which might results in more irrational IVF administration. (33)

Rationality of IVF administration in this study can only be assessed in the way IVF resuscitation were given to participants with diarrhea based on their dehydration level and the result shows more questions rather than answers. Maintenance fluid administration was needed in surgical patients (congenital megacolon, hernia, phimosis, etc.). However, for the rest of those who receive maintenance fluid without accompanying IV drugs and specific indications (e.g. dengue fever and febrile convulsion) which necessitate IVF treatment, its rationale requires further assessment on the patient's ability to intake fluids orally as stated by the NICE guideline. (6)

\section{Conclusion}

This study provides the information of intravenous fluid use pattern in 0-18 months children cohort in Indonesia. Some intravenous fluids were found to be unnecessary and not optimal, exposing the patients to the avoidable risks. These data justify the further study to evaluate intravenous fluid use in children and the needs of continuing training on intravenous fluid management among healthcare providers.

\section{Declarations}

Ethics approval and consent to participate

Ethics approval for the latest version of protocol (version 8, 19 Aug 2015) was obtained from Medical and Health Research Ethics Committee of Faculty of Medicine Universitas Gadjah Mada - Dr Sardjito General Hospital (ref. no. KE/FK/1040/EC) and the Royal Children's Hospital Melbourne Human research Ethics Committee (ref. no. 32060 D). All methods were performed in accordance with the International Conference on Harmonization - Good Clinical Practice (ICH-GCP) and other relevant guidelines and regulations. Approval of clinical trial conduct was obtained from Indonesian National Agency of Drug and Food Control (Ref. No. PN.01.06.1.31.11.12.7533, date: 23 November 2012). Written informed consents were obtained from the parents or guardians of every child during the RV3-BB phase Ilb trial. This post-hoc analysis only included those participants who gave consent for their data in the future studies.

Consent for publication

Not applicable

Availability of data and materials

The datasets used and analysed during the current study are available from the corresponding author on reasonable request.

Competing interests

N.S.B. is employee of PT Bio Farma who provided funds to support this study. All other authors declare that they have no known competing financial interests or personal relationships that could have appeared to influence the work reported in this paper.

Funding

This trial was funded by the Bill and Melinda Gates Foundation, the National Health and Medical Research Council, and PT Bio Farma.

Authors' contributions

JAT, CDS, KPJ, and EW made substantial contributions to designing the study, analyzing the data, interpreting the results, writing and revising the manuscript. $\mathrm{JHH}, \mathrm{JS}, \mathrm{AH}$ made contributions to analyzing the data and interpreting the results. NSB, JEB and YS made contributions to review the study. All authors

Page 14/17 
reviewed and approved of the final version of the manuscript.

Acknowledgements

We would like to show our gratitude to the research team of RV3 Rotavirus Vaccine Program from Murdoch Children's Research Institute, Bio Farma, and Center for Child Health. We would also like to thank our colleagues from Dr. Sardjito General Hospital (Yogyakarta), Soeradji Tirtonegoro General Hospital (Klaten), Sleman General Hospital (Sleman), and participating PHCs. We also thank all project managers, research assistants, study site staffs especially the midwives who have monitored the medications received by the participants, and participants' parents in Sleman and Klaten district who have been cooperating in this study. Finally, we would like to acknowledge our colleagues from Sleman and Klaten District Health Office for field research support.

\section{References}

1. Feld LG, Neuspiel DR, Foster BA, Leu MG, Garber MD, Austin K, et al. Clinical Practice Guideline: Maintenance Intravenous Fluids in Children. Pediatrics. 2018 Dec;142(6):e20183083.

2. World Health Organization. Guidelines for the Management of Common Childhood Illnesses. WHO Library Cataloguing-in-Publication Data World. 2013. p. 125-43.

3. Moritz ML, Ayus JC. Intravenous fluid management for the acutely ill child. Curr Opin Pediatr. 2011;23(2).

4. McNab S. Intravenous maintenance fluid therapy in children. J Paediatr Child Health. 2016 Feb;52(2):137-40.

5. Lobo D, Lewington A, Allison S. Basic Concepts of Fluid and Electrolyte Balance. 2013.

6. National Clinical Guideline Center. Intravenous fluid therapy: Intravenous fluid therapy in adults in hospital. NICE Guidel. 2013;

7. Terris M, Crean P. Fluid and electrolyte balance in children. Anaesth Intensive Care Med. 2017 Nov;18(11):567-71.

8. Conn RL, McVea S, Carrington A, Dornan T. Intravenous fluid prescribing errors in children: Mixed methods analysis of critical incidents. PLoS One. 2017 Oct;12(10):e0186210.

9. Ben Abdelaziz R, Hafsi H, Hajji H, Boudabous H, Ben Chehida A, Mrabet A, et al. Full title: Peripheral venous catheter complications in children: Predisposing factors in a multicenter prospective cohort study. Vol. 17, BMC Pediatrics. 2017.

10. Holloway KA. Pharmaceuticals in Health Care Delivery. Mission Rep. 2011;30.

11. At Thobari J, Satria CD, Ridora Y, Watts E, Handley A, Samad S, et al. Antimicrobial use in an Indonesian community cohort 0-18 months of age. Gurgel RQ, editor. PLoS One. 2019 Aug;14(8):e0219097.

12. At Thobari J, Satria CD, Ridora Y, Watts E, Handley A, Standish J, et al. Non-antibiotic Medication Use in an Indonesian Community Cohort 0-18 Months of Age. PLoS One. 2020;15(11).

13. Bines JE, At Thobari J, Satria CD, Handley A, Watts E, Cowley D, et al. Human neonatal rotavirus vaccine (RV3-BB) to target rotavirus from birth. N Engl J Med. 2018;378(8):719-30.

14. WHO Collaborating Centre for Drug Statistics Methodology. WHOCC - ATC/DDD Index.

15. Indonesian Ministry of Health. Manajemen Terpadu Balita Sakit (MTBS). 2008;

16. National Clinical Guideline Center. IV fluid therapy in adults: Appendices A-Q. NICE Guidel. 2013;238.

17. Badan Pengawas Obat dan Makanan RI. Cek Produk BPOM - BPOM RI.

18. Reddi AS. Intravenous Fluids: Composition and Indications BT - Fluid, Electrolyte and Acid-Base Disorders: Clinical Evaluation and Management. In: Reddi AS, editor. Cham: Springer International Publishing; 2018. p. 35-49.

19. National Clinical Guideline Centre. IV fluids in children: Intravenous fluid therapy in children and young people in hospital. NICE Guidel. $2015 ; 26$.

20. Chopra V, Flanders SA, Saint S, Woller SC, O'Grady NP, Safdar N, et al. The Michigan appropriateness guide for intravenous catheters (MAGIC): Results from a multispecialty panel using the RAND/UCLA Appropriateness Method. Ann Intern Med. 2015 Sep;163(6):S1-39.

21. Currie M, Huecker MR. Ultrasound Intravascular Access. StatPearls. StatPearls Publishing; 2019.

22. Ortega R, Sekhar P, Song M, Hansen CJ, Peterson L. Peripheral intravenous cannulation. N Engl J Med. 2008 Nov;359(21).

23. Limm El, Fang X, Dendle C, Stuart RL, Egerton Warburton D. Half of all peripheral intravenous lines in an Australian tertiary emergency department are unused: Pain with no gain? Ann Emerg Med. 2013 Nov;62(5):521-5.

24. Anigilaje EA. Management of diarrhoeal dehydration in childhood: A review for clinicians in developing countries. Vol. 6, Frontiers in Pediatrics. Frontiers Media S.A.; 2018.

25. Ikatan Dokter Anak Indonesia. Pedoman pelayanan medis. 1st ed. Handryastuti S, Idris NS, Gandaputra EP, Harmoniati ED, Yuliarti K, editors. Jakarta, Indonesia: Badan Penerbit Ikatan Dokter Anak Indonesia; 2009.

26. Holliday MA, Segar WE. THE MAINTENANCE NEED FOR WATER IN PARENTERAL FLUID THERAPY. Pediatrics. 1957;19(5).

27. Caldwell N, Williams L, Rackham O, Morecroft C. DO WE STILL "TREAT” CHILDREN WITH HYPOTONIC INTRAVENOUS FLUIDS? Arch Dis Child. 2015 Jun;100(6):e1.34-e1.

28. New H V., Berryman J, Bolton-Maggs PHB, Cantwell C, Chalmers EA, Davies T, et al. Guidelines on transfusion for fetuses, neonates and older children. Br J Haematol. 2016 Dec;175(5):784-828.

29. Doctor A, Cholette JM, Remy KE, Argent A, Carson JL, Valentine SL, et al. Recommendations on RBC transfusion in general critically ill children based on hemoglobin and/or physiologic thresholds from the pediatric critical care transfusion and Anemia expertise initiative. Vol. 19, Pediatric Critical Care 
Medicine. 2018. p. S98-113.

30. World Health Organization (WHO) and the Special Programme for Research and Tropical Diseases (TDR). CLINICAL MANAGEMENT AND DELIVERY OF CLINICAL SERVICES. In: Dengue: Guidelines for Diagnosis, Treatment, Prevention and Control: New Edition. World Health Organization; 2009. p. $23-55$.

31. Farasatinasab M, Amouzegar A, Safari S, Ghanbari B, Darkahian M, Emami S, et al. Albumin utilization evaluation in a major teaching hospital in Iran: Recommendations for guideline development. J Res Pharm Pract. 2018;7(3):157.

32. Caraceni P, Tufoni M, Bonavita ME. Clinical use of albumin. Vol. 11, Blood Transfusion. SIMTI Servizi; 2013. p. s18.

33. Mahapatra T, Mahapatra S, Banerjee B, Mahapatra U, Samanta S, Pal D, et al. Predictors of rational management of diarrhea in an endemic setting: Observation from India. Vol. 10, PLoS ONE. 2015.

\section{Figures}

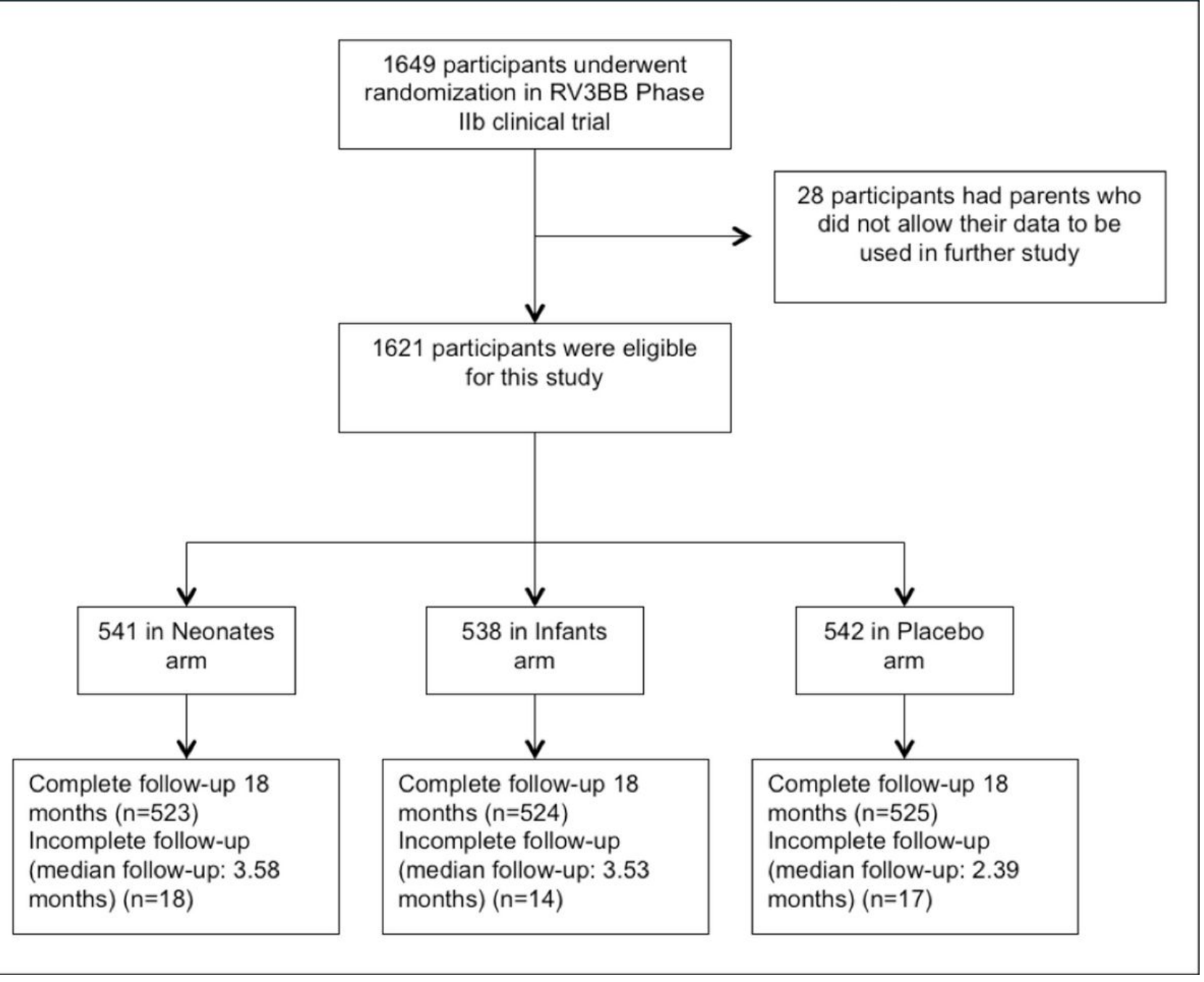

Figure 1

Flow diagram of participants follow-up 


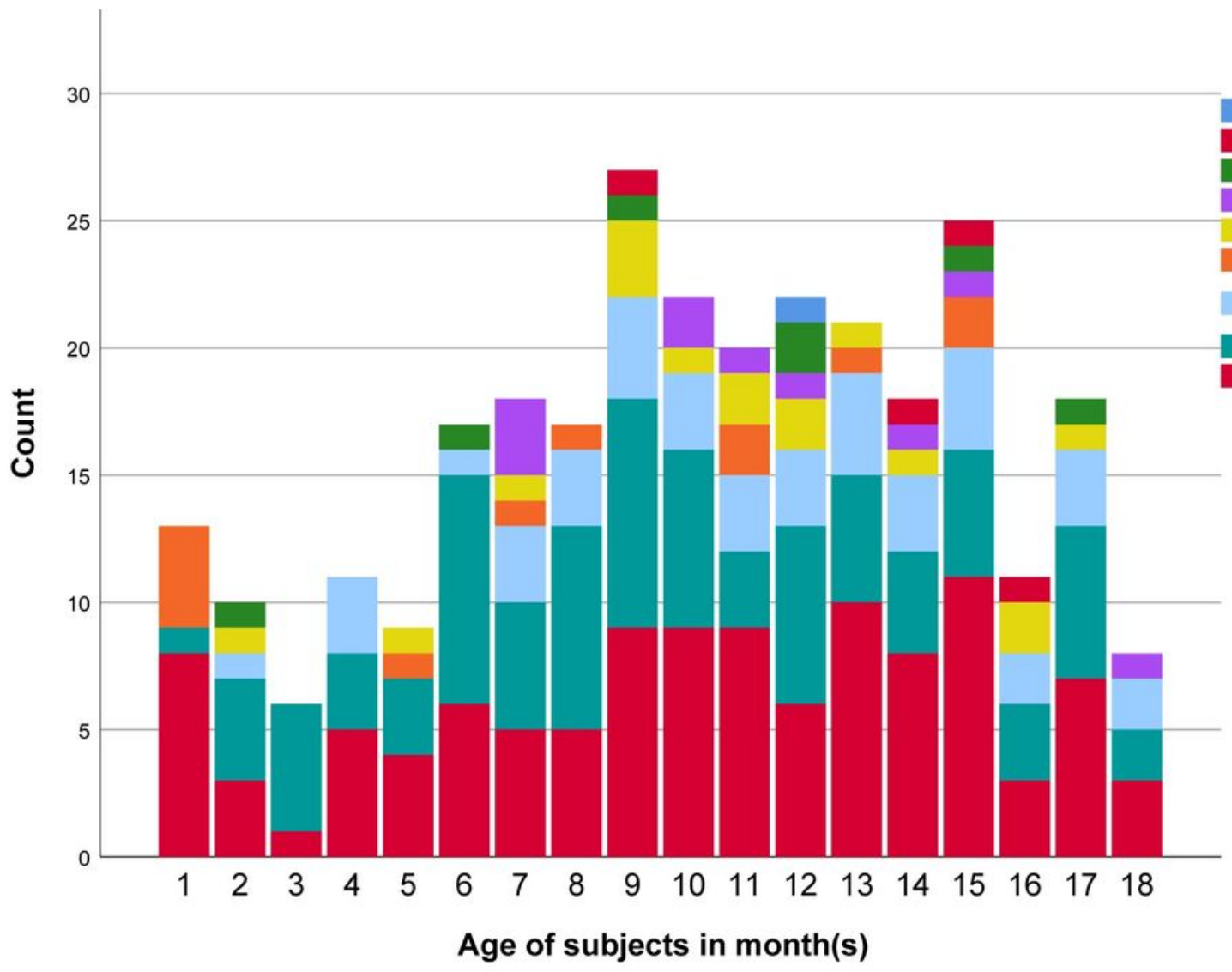

MedDRA diagnosis categories

Ocular disorder

Other disorders

Pyrexia

Other viral infections

Genitourinary system disorders

Other infections disease

Central-peripheral nervous

system

Respiratory system disorders

Gastrointestinal disorders

Figure 2

Age of participants at the start of each adverse event (in Months)

\section{Supplementary Files}

This is a list of supplementary files associated with this preprint. Click to download.

- DatasetIVFUsageinChildrenv28Jan2021.xlsx 